\title{
Census of migrating raptors at Breginjski Stol (NW Slovenia) - the FIRST CONFIRMED BOTTLENECK SITE IN SLOVENIA
}

\section{Popis selečih se ujed na Breginjskem Stolu (SZ Slovenija) - prvo potrjeno ozko grlo v Sloveniji}

Katarina Denac

DOPPS - BirdLife Slovenia, Tržaška cesta 2, SI-1000 Ljubljana, Slovenia, e-mail: katarina.denac@dopps.si

From 4 to 31 May 2010, raptor migration was monitored daily between 9.00 and $17.00 \mathrm{hrs}$ CET at Breginjski Stol (NW Slovenia). In all, 2,385 raptor passes were counted, belonging to at least 17 species that were divided into resident and migratory birds. Residents ( $\mathrm{n}=875$ passes) foraged, bred or daily migrated over the area. Among them, Griffon Vulture Gyps fulvus was the most frequent species ( $\mathrm{n}=575$ passes) with the largest observed group of 35 individuals on 26 May. In the morning, Griffon Vultures were flying from west to east in search of food, whereas in the afternoon they were returning in the opposite direction to their colony in Forgaria nel Friuli (Italy). Their numbers increased after 15 May, when Croatian Griffons joined those from Italy. Altogether, 1,510 individuals of migratory raptors were counted, belonging to at least nine species. Among them, Honey Buzzard Pernis apivorus was the most common (1,368 ind., $90.6 \%$ of migratory raptors). The migration peak was reached on 14 May, with 552 individuals. Most raptors were seen migrating solitarily or in small flocks (2-4 ind.), whereas on five days (4, 7, 11, 13, 14 May) over $20 \%$ of all observed flocks were either medium-sized (5-15 ind.) or large (> 15 ind.). Raptors mostly migrated between 9.00 and 13.00 hrs. Taking into consideration several factors - short observation period and limited number of observation hours per day, overlooked raptors due to human- and topographyrelated causes, movements of observers between observation points, extremely bad weather and night migration of raptors - we estimate that the actual number of migratory raptors that passed Breginjski Stol in spring 2010 was 3,060-4,660 individuals. Thus, Breginjski Stol is the first confirmed bottleneck site of European importance for migratory raptors in Slovenia, as defined by BirdLife International IBA criterion B1iv, and a natural continuation of migratory pathways from northern Italy.

Key words: census, raptors, spring migration, bottleneck, Breginjski Stol, NW Slovenia

Ključne besede: popis, ujede, spomladanska selitev, ozko grlo, Breginjski Stol, SZ Slovenija

\section{Introduction}

Of European raptor species, at least 38 are fully or partially migratory (ZALLES \& BildSTEIN 2000). On migration, they use two main flight types - flapping (active flight) or soaring and gliding. The former is mainly used by smaller raptors such as falcons and sparrowhawks, especially when thermal convection is absent (e.g. early in the morning, late in the afternoon, and above water) (SPAAR 1999). It enables them to cross large stretches of water or mountain chains on a broad front. In contrast, soaring and gliding is preferred by larger species such as eagles, vultures and buzzards (SPAar \& Bruderer 1997). Most species, including 


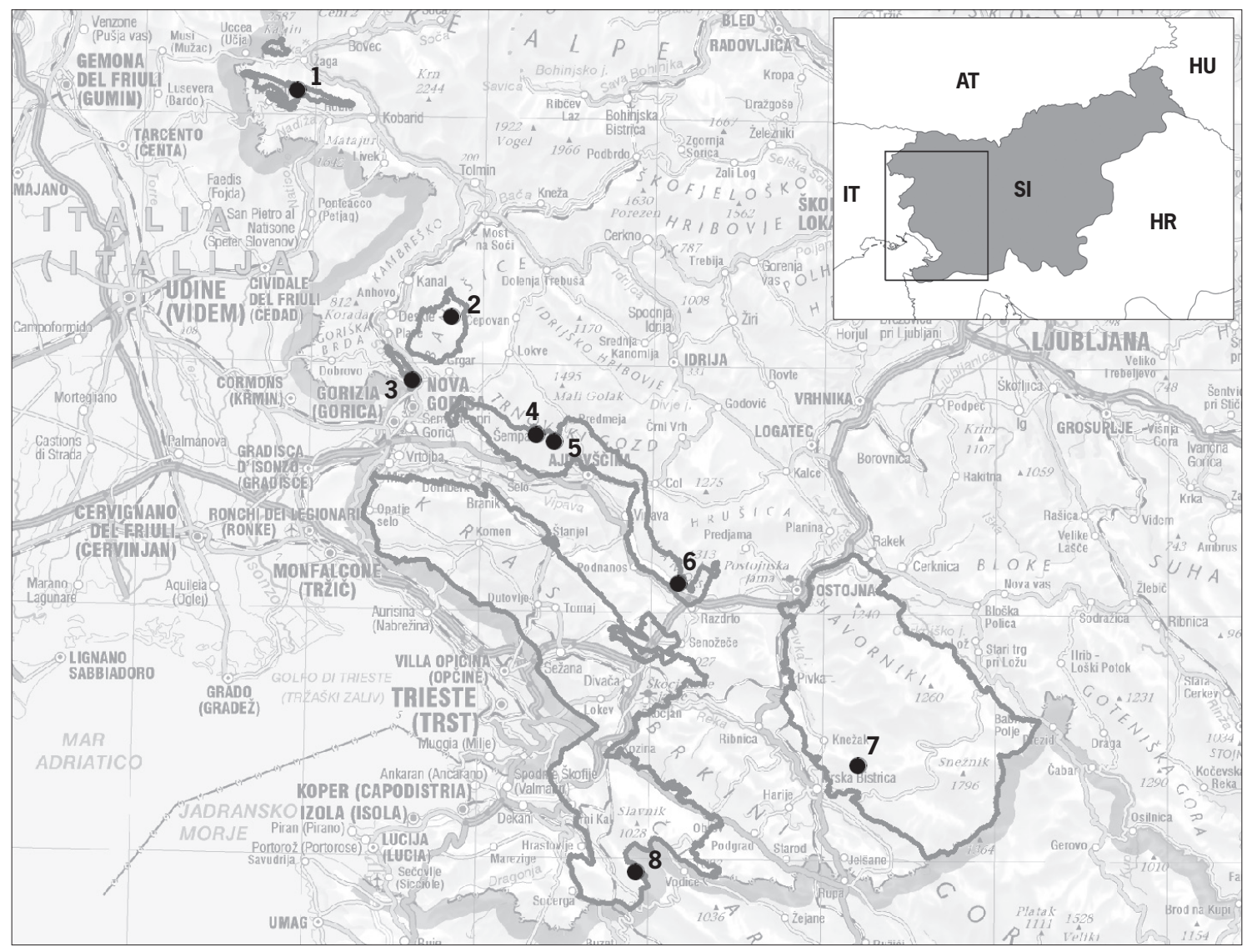

Figure 1: Observation points for raptor migration monitoring in Slovenia in the 2005-2010 period. Observation points are located on elevated localities in the following Important Bird Areas (IBAs): (1) Breginjski Stol - IBA Breginjski Stol and Planja; (2) Banjšice - IBA Banjšice plateau; (3) Sabotin, (4) Kucelj, (5) Mala gora and (6) Nanos - IBA Southern slopes of Trnovo forest and Nanos plateau; (7) Volovja reber - IBA Snežnik plateau and Pivka valley; (8) Golič - IBA Kras.

Slika 1: Opazovalne točke, uporabljene za monitoring selečih se ujed v Sloveniji v obdobju 2005-2010. Točke so bile izbrane na višjih mestih v naslednjih Mednarodno pomembnih območjih za ptice (IBA-jih): (1) Breginjski Stol - IBA Breginjski Stol in Planja; (2) Banjšice - IBA Banjška planota; (3) Sabotin, (4) Kucelj, (5) Mala gora in (6) Nanos - IBA Južna pobočja Trnovskega gozda in Nanoška planota; (7) Volovja reber - IBA Snežniška planota in Pivška dolina; (8) Golič - IBA Kras.

harriers Circus sp. and Honey Buzzards Pernis apivorus, alternate between these two flight types, which allows them to migrate under various environmental conditions and to prolong daily migration time (Bruderer et al. 1994, SpaAr \& Bruderer 1997). Thermals necessary for soaring only occur over land (SPAAR \& BRUderer 1997), which results in regular and predictable raptor aggregations at specific geographic features, especially along mountain ridges and passes, narrow coastal plains, isthmuses, and peninsulas (Zalles \& Bildstein 200o). These are called bottlenecks. According to BirdLife IBA criterion B1iv, a site qualifies as a bottleneck for migratory raptors if 3,000 or more raptors pass through it on spring or autumn migration (HeATH \& Evans 2000). Most raptors are reluctant to cross large waterbodies (wider than 25 $\mathrm{km}$ ), therefore they concentrate at places that enable them to reduce the length of water crossing, such as the Strait of Gibraltar, Bosporus and the Strait of Messina in the Mediterranean (Zalles \& Bildstein 2000). Census of raptors on their spring or autumn migration at bottleneck sites is a very efficient way of monitoring the size of their population (Busse et al. 2002, Agostini et al. 2007) and a cost-effective method of assessing their conservation status (ZALLES \& BILDSTEIN 2000). This is especially true for elusive species such as Honey Buzzard which are hard to monitor at breeding sites (Agostini $e t$ al. 2007). 


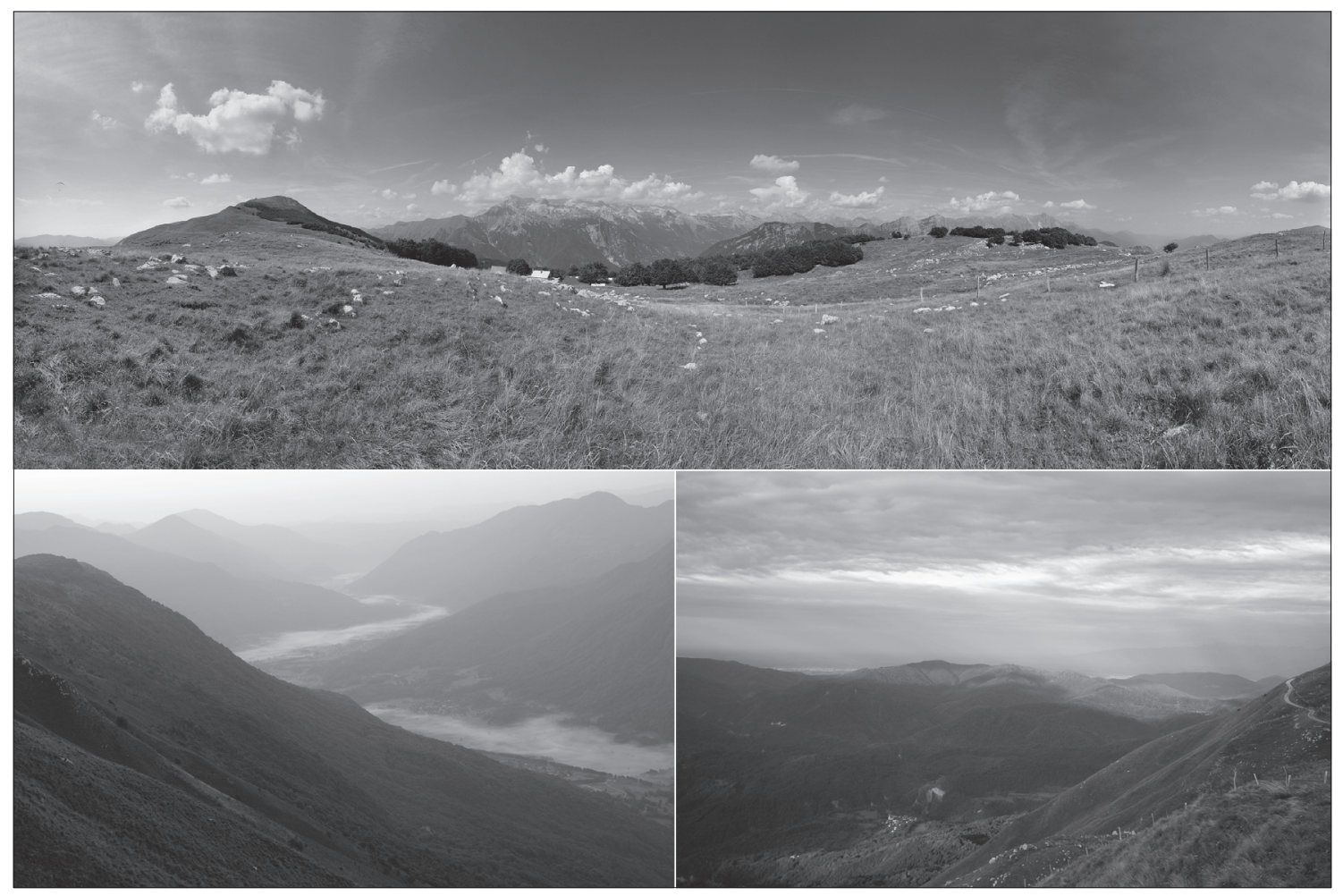

Figure 2: Breginjski Stol - view west of observation point Mali vrh (1,405 m a.s.l.) along the ridge towards the summit of Stol (1,673 m a.s.I.) and Kanin Mts in the background in the middle (top) (photo: A. Jagodnik); view west of observation point Mali vrh of Breginjski kot, with lowland Friuli (Italy) in the background (bottom right) (photo: D. Bordjan) and view east of observation point Mali vrh towards the town of Kobarid and the Nadiža valley bellow, with the Upper Soča valley in the background (bottom left) (photo: A. Jagodnik)

Slika 2: Breginjski Stol - pogled zahodno od opazovalne točke Mali vrh (1405 m n.v.) vzdolž grebena proti vrhu Stola (1673 m n.v.) in Kaninskemu pogorju na sredini slike v ozadju (zgoraj) (foto: A. Jagodnik); pogled zahodno od opazovalne točke Mali vrh na Breginjski kot, z nižinsko Furlanijo (Italija) v ozadju (spodaj desno) (foto: D. Bordjan); pogled vzhodno od opazovalne točke Mali vrh proti mestu Kobaridu in dolini Nadiže spodaj, z Zgornjo Soško dolino v ozadju (spodaj levo) (foto: A. Jagodnik)

In Slovenia, DOPPS - BirdLife Slovenia has been monitoring migrating raptors since 2005. Data has been gathered at five different Important Bird Areas (IBA) (Breginjski Stol and Planja, Southern slopes of Trnovo forest and Nanos plateau, Kras, Snežnik plateau and Pivka valley, Banjšice plateau), with Breginjski Stol and Snežnik - Pivka being monitored most often (four and three times, respectively) (Figure 1).

Data gathered in 2003-2009 indicated that there is a bottleneck for migratory raptors in western Slovenia, specifically on Breginjski Stol. The aim of our study was to confirm or refute this assumption through daily observations made in part of spring migration period.

\section{Study area and method}

\subsection{Study area}

In May 2010, we monitored migrating raptors on $\mathrm{Mt}$ Stol above Breginjski kot (hereinafter referred to as Breginjski Stol) in NW Slovenia (Figures 1, 2 \& 3).

The ridge of Breginjski Stol is located in the Upper Soča valley and constitutes the foothills of the Julian Alps. The ridge follows a west-east direction. Most of it lies in Slovenia and the rest in Italy, where it descends to lowland Friuli north of Udine. The highest summit is Stol (1,673 m a.s.l.) (Figure 2). 


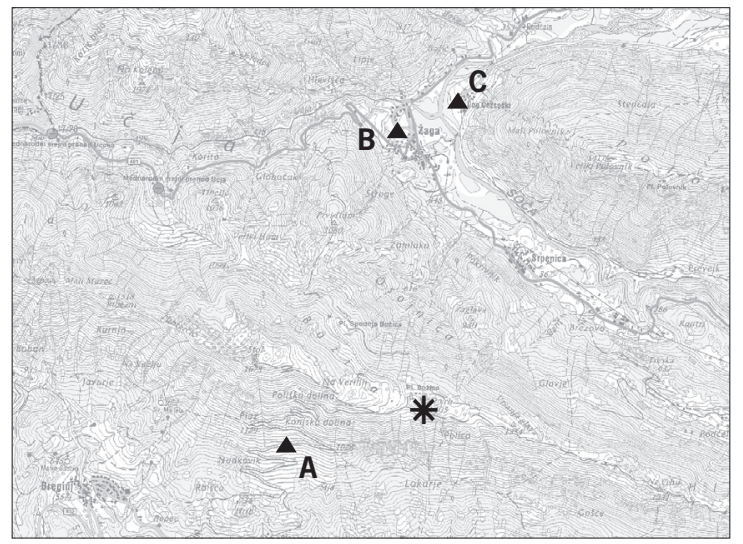

Figure 3: Observation points at Breginjski Stol (asterisk - main observation point Mali vrh, triangles - alternative observation points)

Figure 3: Opazovalne točke na Breginjskem Stolu (zvezdica - glavna opazovalna točka Mali vrh, trikotniki - alternativne opazovalne točke)

The slopes are very steep (average inclination $33^{\circ}$ ). At Breginjski Stol, migrating raptors from Italy first encounter high mountain obstacle after passing the Po plain when returning to their breeding grounds. To the north and south of Breginjski Stol, there are two river valleys, which are the lowest mountain passes in a west-east direction in the area (Učja and Nadiža valley, respectively). Tree line on the southern slope of Breginjski Stol lies at approximately 1,000 $\mathrm{m}$ a.s.l., which is a result of anthropogenic activities (mowing, pasture). Thus, the southern slope from $1,000 \mathrm{~m}$ a.s.l. upwards is covered with extensively managed grasslands. The northern slope is covered by beech forest up to $1,600 \mathrm{~m}$ a.s.l. The area is characterized by high annual amount of precipitation (> 3,000 $\mathrm{mm}$ per year) and frequent fog. The average annual temperature is around $5^{\circ} \mathrm{C}$. Hail showers are a common phenomenon in spring and especially in summer (Fridl et al. 1998, Peršolja 2006). Paragliders regularly use the area after 1 May.

\subsection{Method}

Raptors were monitored from 4 to 31 May 2010 (28 days). This period was chosen as it covers the peak of spring migration in Honey Buzzard (CrAmp 1980), a species for which we had some indications that it passes Breginjski Stol in large numbers (BožIČ 2004, Rubinić et al. 2005, Rubinić 2009). Our main observation point was located at Mali vrh $(1,405$ $\mathrm{m}$ a.s.l.; $\left.46^{\circ} 16^{\prime} 21.69^{\prime \prime} \mathrm{N}, \quad 13^{\circ} 29^{\prime} 0.01^{\prime \prime} \mathrm{E}\right)$. Three alternative observation points were chosen for instances of rainy and foggy weather: point A - southern slope of Breginjski Stol (950 m a.s.l.; 46 $166^{\prime} 5.28^{\prime \prime N}$, $\left.13^{\circ} 27^{\prime} 33.11^{\prime \prime} \mathrm{E}\right)$, point B - slightly above the village of Žaga towards the Učja border crossing ( $400 \mathrm{~m}$ a.s.l.; $46^{\circ} 18^{\prime} 23.24$ "N $\left.13^{\circ} 28^{\prime} 40.08^{\prime \prime} \mathrm{E}\right)$ and point $\mathrm{C}$ in the village of Log Čezsoški (350 m a.s.l.; 46¹8'36.93” N, $13^{\circ} 29^{\prime} 18.12$ ”E) (Figure 3).

Daily monitoring lasted from 9.00 to $17.00 \mathrm{hrs}$ CET (i.e. $8 \mathrm{~h}$ per day). We interrupted the survey in the event of showers and storms and continued when the weather allowed us to do so, or moved to alternative points. On days of bad weather on all observation points (prolonged rain, thick fog), monitoring lasted less than $8 \mathrm{~h} /$ day.

Two or more observers were present at the observation point simultaneously, except for 7 May when only one observer was present. Observers constantly scanned the sky with binoculars and telescopes (20-60× magnification), covering as much sky as possible.

The following weather conditions were noted at the beginning of monitoring and thereafter at the beginning of each hour:

- wind (direction from which it was blowing, N, S, W, E, NE, SE, NW, SW; intensity 0-4),

- precipitation (type: rain, snow, hail; intensity 0-4), - cloud cover (\%),

- visibility $(\mathrm{km})$.

For wind and precipitation the intensity codes were as follows: 0 - no wind or precipitation, 1 - slight, 2 - medium, 3 - strong, 4 - very strong wind or precipitation.

Greater weather changes were noted more frequently. Temperature was not recorded.

Each raptor observation was numbered in the form and on the map with the same number. Raptors were determined to the species level. Where this was not possible they were determined to the lowest possible taxonomic level, e.g. Falco sp. Species were sexed and aged if possible. Data on their numbers, exact time of observation, direction of flight and, less consistently, data on their flight altitudes were recorded. Course of their flight was delineated on the map.

Observations of resident Kestrels Falco tinnunculus and Common Buzzards Buteo buteo were entered into a separate form. Data for residents (incl. Griffon Vulture Gyps fulvus, Golden Eagle Aquila chrysaetos, Hobby F. subbuteo, Peregrine Falcon F. peregrinus, Goshawk Accipiter gentilis and Sparrowhawk A. nisus) were not further analysed, with the exception of Griffon Vulture that occurs in the area in high numbers and arrives from Italy. 
Table 1: Observation parameters of migrating raptor census at Breginjski Stol in May 2010

Tabela 1: Opazovalni parametri štetja selečih se ujed na Breginjskem Stolu maja 2010

\begin{tabular}{|c|c|c|c|c|c|c|}
\hline $\begin{array}{l}\text { Date/ } \\
\text { Datum }\end{array}$ & $\begin{array}{l}\text { Cloudiness/ } \\
\text { Oblačnost } \\
(\%)\end{array}$ & $\begin{array}{l}\text { Wind / Veter } \\
\text { (intensity, } \\
\text { direction / jakost, } \\
\text { smer) }\end{array}$ & $\begin{array}{l}\text { Precipitation/ } \\
\text { Padavine }\end{array}$ & $\begin{array}{l}\text { Duration of } \\
\text { observation/ } \\
\text { Trajanje } \\
\text { opazovanja }\end{array}$ & $\begin{array}{c}\text { No. of } \\
\text { observers/ } \\
\text { Št. } \\
\text { opazovalcev }\end{array}$ & $\begin{array}{l}\text { Observation } \\
\text { point/ } \\
\text { Opazovalna } \\
\text { točka }\end{array}$ \\
\hline 4.5 . & IOO & $0-2, S W$ & rain / dež & $4 \mathrm{~h} 30 \mathrm{~min}$ & 2 & Mali vrh \\
\hline 5.5 & IOO & $\mathrm{I}-3, \mathrm{E}, \mathrm{NE}, \mathrm{S}$ & rain / dež & $8 \mathrm{~h} 5 \mathrm{~min}$ & 2 & Mali vrh \\
\hline 6.5 . & $90-100$ & $2-4, S$ & $\begin{array}{l}\text { rain, once inbetween hail/ } \\
\text { dež, enkrat vmes toča }\end{array}$ & $7 \mathrm{~h} 55 \mathrm{~min}$ & 2 & A \\
\hline 7.5 . & 20-10O & O-I, W & no / ne & $9 \mathrm{~h} 25 \mathrm{~min}$ & I & A \\
\hline 8.5 . & 100 & I, W & rain / dež & $5 \mathrm{~h}$ & 2 & A \\
\hline 9.5 . & O-IOO & $\begin{array}{c}\text { I-2, N, S, SEE, } \\
\text { SW }\end{array}$ & occasional rain / občasen dež & $9 \mathrm{~h} 25 \mathrm{~min}$ & 2 & A \\
\hline I0.5. & IOO & o & rain / dež & $3 \mathrm{~h} 35 \mathrm{~min}$ & 2 & $\mathrm{C}$ \\
\hline II.5. & IOO & O-I, SE, NW & occasional rain / občasen dež & $6 \mathrm{~h} 5 \mathrm{~min}$ & 2 & A \\
\hline I2.5. & IOO & o & no / ne & $2 \mathrm{~h} 25 \mathrm{~min}$ & 2 & A \\
\hline I3.5. & IOO & $\mathrm{I}, \mathrm{SE}$ & occasional rain / občasen dež & $9 \mathrm{~h} 45 \mathrm{~min}$ & 2 & A \\
\hline I4.5. & IOO & $\mathrm{I}-3, \mathrm{NW}, \mathrm{N}$ & occasional rain / občasen dež & $7 \mathrm{~h}$ Io min & 2 & A \\
\hline 15.5 . & IOO & $\mathrm{I}-3, \mathrm{NE}$ & occasional rain / občasen dež & II h $30 \mathrm{~min}$ & 3 & A \\
\hline I6.5. & $90-100$ & I & no / ne & $9 \mathrm{~h} 30 \mathrm{~min}$ & 3 & A \\
\hline 17.5. & $50-100$ & I-2, NE, SW & no / ne & $9 \mathrm{~h} 50 \mathrm{~min}$ & 2 & Mali vrh \\
\hline I8.5. & $50-75$ & I, $S$ & no/ ne & $8 \mathrm{~h} 20 \mathrm{~min}$ & 2 & Mali vrh \\
\hline 19.5. & $0-25$ & $\mathrm{O}-2, \mathrm{~N}$ & no / ne & $8 \mathrm{~h} \mathrm{I} 5 \mathrm{~min}$ & 2 & Mali vrh \\
\hline 20.5. & $40-90$ & $\mathrm{I}-3, \mathrm{~N}, \mathrm{NE}$ & no / ne & II h $20 \mathrm{~min}$ & 2 & Mali vrh \\
\hline 21.5 & $50-100$ & O-2, N, SW & no/ ne & $\mathrm{I} 2 \mathrm{~h} 5 \mathrm{~min}$ & 2 & Mali vrh \\
\hline 22.5 . & $20-80$ & $\begin{array}{l}\text { o-I, W, SE, } \\
\text { SW, S }\end{array}$ & occasional rain / občasen dež & $\mathrm{I} 2 \mathrm{~h} 20 \mathrm{~min}$ & 2 & A \\
\hline 23.5 . & $25-95$ & I, E, NE & occasional rain / občasen dež & $9 \mathrm{~h} 30 \mathrm{~min}$ & 2 & Mali vrh \\
\hline 24.5 . & $5-100$ & $\mathrm{I}-2, \mathrm{~S}, \mathrm{~W}$ & $\begin{array}{l}\text { rain at the end of survey/ } \\
\text { dež na koncu popisa }\end{array}$ & $9 \mathrm{~h}$ & 2 & Mali vrh \\
\hline 25.5 & O-IOO & $\mathrm{I}-3, \mathrm{~S}, \mathrm{~W}$ & no/ ne & $8 \mathrm{~h}$ & 3 & Mali vrh \\
\hline 26.5 . & $80-100$ & $I-2, S$ & no/ ne & $9 \mathrm{~h} 20 \mathrm{~min}$ & 2 & Mali vrh \\
\hline 27.5 & $40-60$ & $\mathrm{I}-2, \mathrm{~S}, \mathrm{SW}$ & no/ ne & $9 \mathrm{~h}$ & 2 & A \\
\hline 28.5 . & IO-IOO & $2, S, S W$ & rain / dež & $6 \mathrm{~h} 30 \mathrm{~min}$ & 2 & Mali vrh \\
\hline 29.5 . & $70-100$ & $\mathrm{I}-3, \mathrm{~S}, \mathrm{~N}$ & $\begin{array}{l}\text { rain from } 12.00 \text { hrs onwards, } \\
\text { once inbetween hail/ } \\
\text { dež od } 12.00 \text { h naprej, enkrat } \\
\text { vmes toča }\end{array}$ & $8 \mathrm{~h}$ io $\mathrm{min}$ & 2 & Mali vrh \\
\hline 30.5 . & IOO & $\mathrm{I}-2, \mathrm{E}, \mathrm{W}, \mathrm{N}$ & rain / dež & $8 \mathrm{~h}$ & 2 & A \\
\hline 31.5. & $5-80$ & $2, \mathrm{~N}$ & $\begin{array}{l}\text { snow shower at } 16.00 \mathrm{hrs,} \\
\text { otherwise no precipitation/ } \\
\text { snežna nevihta ob } 16.00 \mathrm{~h} \text {, } \\
\text { drugače brez padavin }\end{array}$ & $6 \mathrm{~h} 55 \mathrm{~min}$ & 3 & Mali vrh \\
\hline
\end{tabular}

Codes for wind intensity: 0 - no wind, 1 - slight, 2 - medium, 3 - strong, 4 - very strong wind; cloudiness was estimated as $\%$ of sky covered in clouds. Observation point: given is the location of the point from which most observations were made (see Figure 3 for location of points) / Kode za jakost vetra: 0 - brez vetra, 1 - rahel, 2 - srednji, 3 - močan, 4 - zelo močan veter; oblačnost je bila ocenjena kot \% neba pokritega z oblaki. Opazovalna točka: navedena je lokacija točke s katere je bila opravljena večina opazovanja (glej sliko 3 za lokacije točk) 

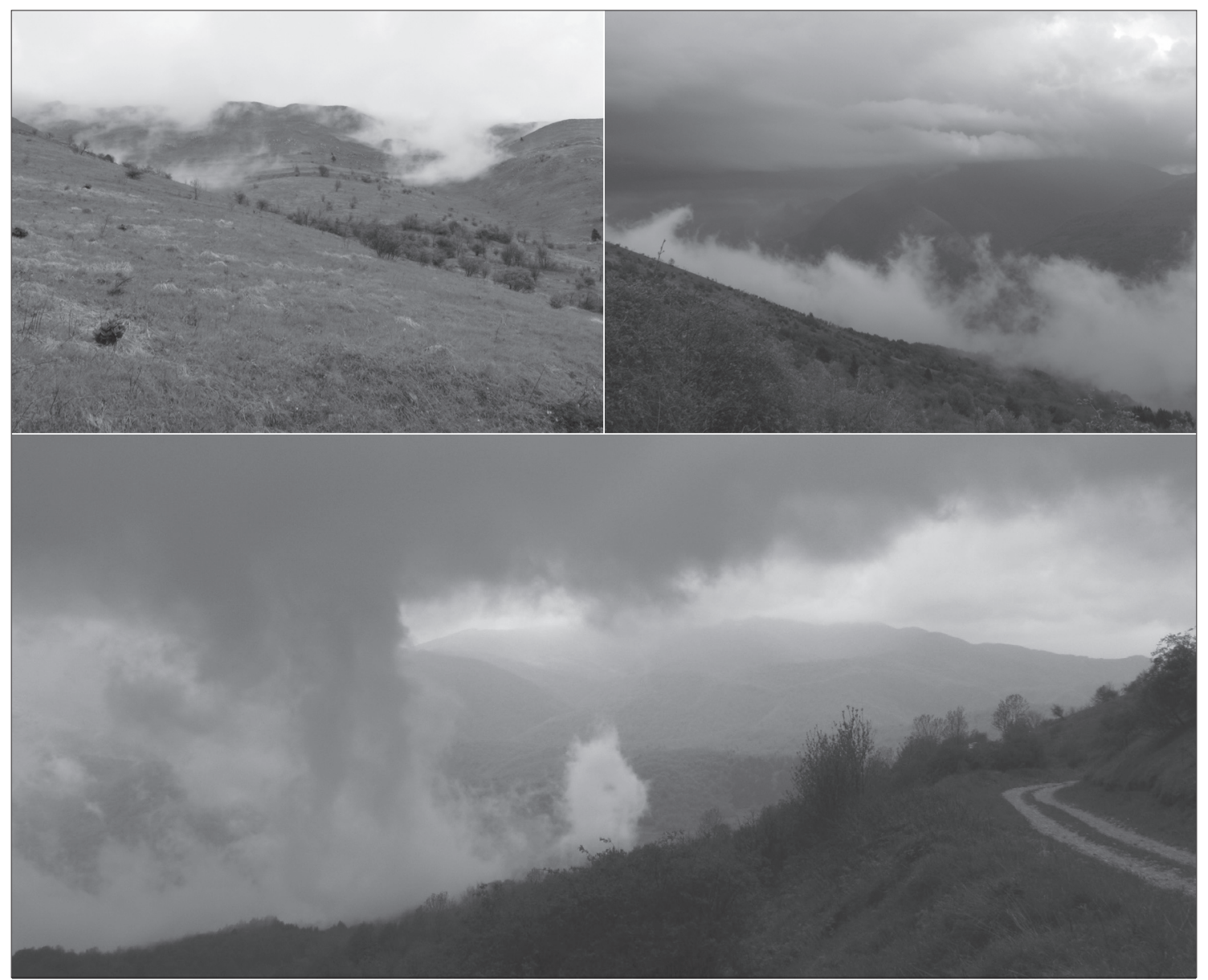

Figure 4: Fog on the summit and slopes of Breginjski Stol above 1,100 m a.s.l. (top left), in the Nadiža valley (top right), and a belt of relatively good visibility (below) at observation point A on 14 May 2010 (photo: J. Figelj)

Slika 4: Megla na vrhu in pobočjih Breginjskega Stola nad 1100 m n.v. (zgoraj levo), v dolini Nadiže (zgoraj desno), in pas z razmeroma dobro vidljivostjo (spodaj) na opazovalni točki A 14.5.2010 (foto: J. Figelj)

In data analysis, flock size was determined as: solitary birds, small (2-4 ind.), medium-sized (5-15 ind.) or large flocks (> 15 ind.).

\section{Results}

\subsection{Observation conditions}

We monitored raptor migration continuously for 28 days, which amounted to 231 observation hours (average $8 \mathrm{~h} 25 \mathrm{~min} /$ day). Throughout the entire study period, weather was extremely foggy and rainy, which hindered our survey. Even on days that started with sunny weather and clear sky, clouds soon began to accumulate, fog developed and lifted from the Nadiža valley, and showers from above Mija and Matajur Mts (south of Nadiža valley) spread to Breginjski Stol. Wind conditions were often very heterogeneous throughout the day (Table 1). For a substantial part of May, fog was covering the summit and slopes above ca. $1,100 \mathrm{~m}$ a.s.l. and quite often also the Nadiža valley. Therefore, almost half the observations were done from alternative point $A$ on the southern slope of Breginjski Stol, which enabled a better view of the migrating raptors than from the two other alternative points (Figure 4).

\subsection{Number of raptors}

\subsubsection{Total number of raptors}

In total, we counted 2,385 raptor passes belonging to at least 17 different species (Tables $2 \& 3$ ). These can 

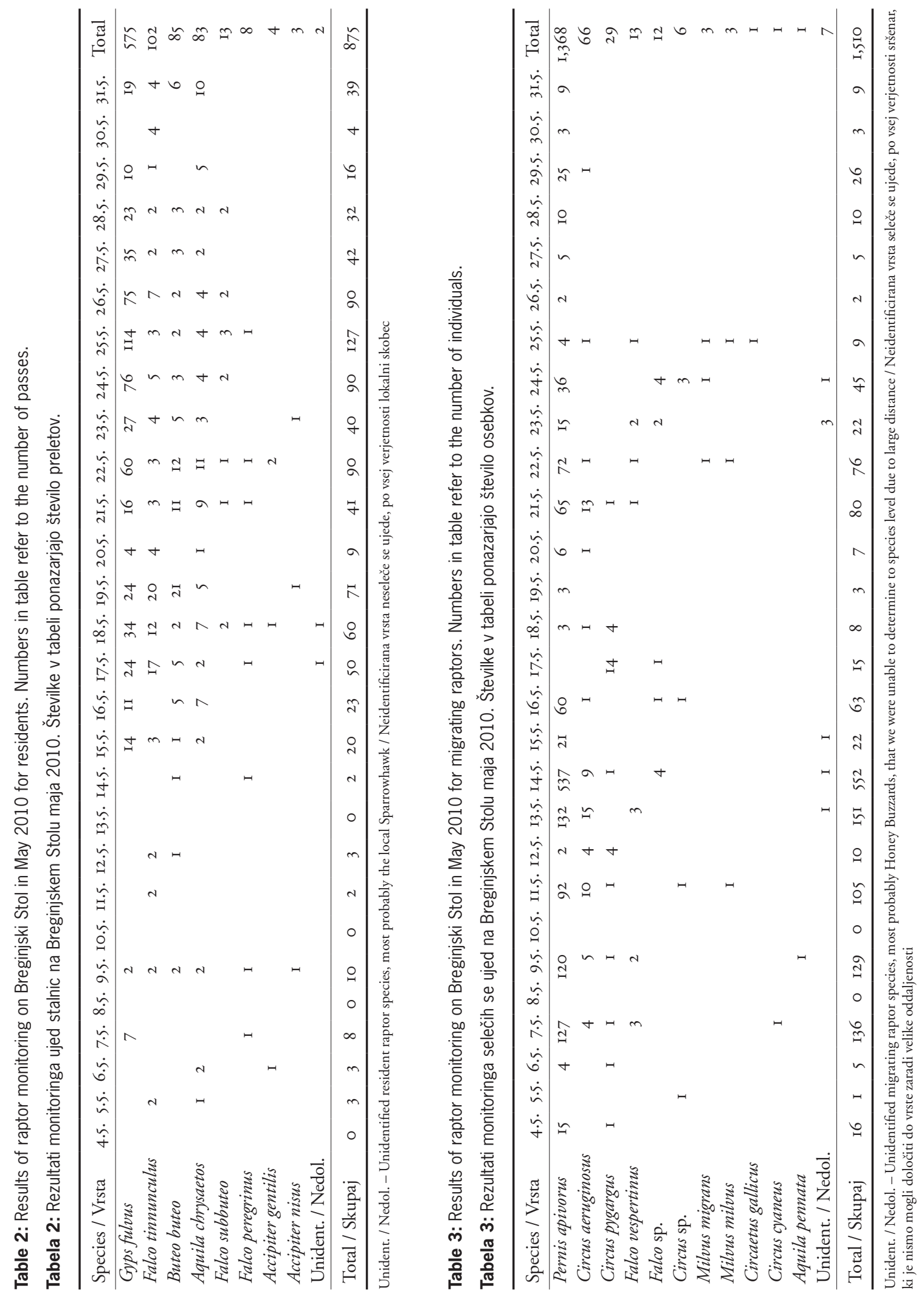


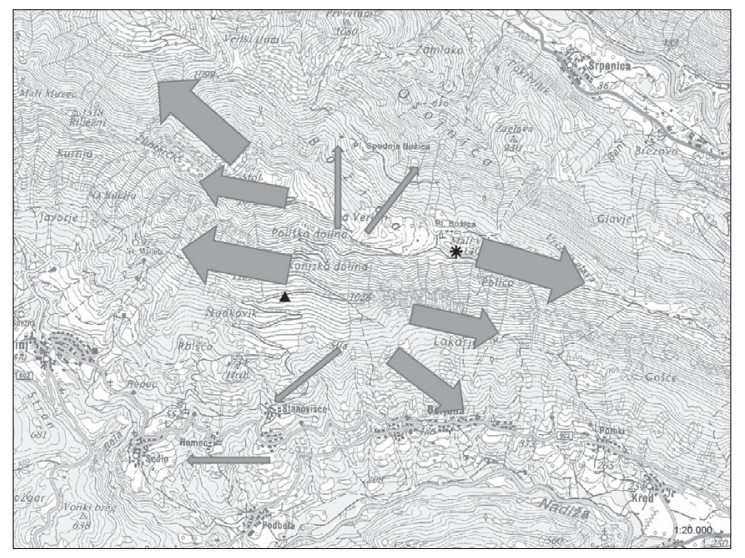

Figure 5: Flight directions of Griffon Vultures Gyps fulvus on Breginjski Stol in May 2010 ( $n=493$ passes). The thickness of arrows delineates different percentages of Griffon Vulture passes: narrow $0-4 \%$, middle-sized $5-15 \%$ and thick $>15 \%$. Asterisk - main observation point, triangle - point $A$.

Slika 5: Smeri letov beloglavih jastrebov Gyps fulvus na Breginjskem Stolu maja 2010 ( $n=493$ preletov). Debelina puščic ponazarja različne odstotke preletov beloglavih jastrebov: ozka 0-4\%, srednje debeline $5-15 \%$ in debela > 15\%. Zvezdica - glavna opazovalna točka, trikotnik - točka A.

be divided into residents $(\mathrm{n}=875$ passes, Table 2$)$ and migratory species ( $\mathrm{n}=1,510$ ind., Table 3 ). For residents we use the expression "number of passes" instead of "number of individuals", since the same individuals were sometimes double- or even multiplecounted (e.g. Griffon Vultures flew from west to east in the morning, whereas in the afternoon they flew in the opposite direction - we counted them both times). In migratory raptors, individuals were not double-counted, therefore the term "number of individuals" is appropriate. On average we counted 85 raptor passes per day (residents + migratory raptors) and 54 individuals of migrating raptors per day.

\subsubsection{Residents}

Griffon Vulture was the most common species among residents (65.7\% of all resident passes). It was recorded in approximately two thirds of observation days, whereas on other days it was absent most probably due to rainy and foggy weather (e.g. on 4.-6.5., 8.5., 10.-14.5. and 30.5. fog was covering the entire Nadiža valley and / or summit and slope of Breginjski Stol above 1,100 m a.s.l.) (Table 2). The largest group of Griffon Vultures (35 ind.) was observed on 26 May; a somewhat smaller group of 31 individuals was observed a day earlier.

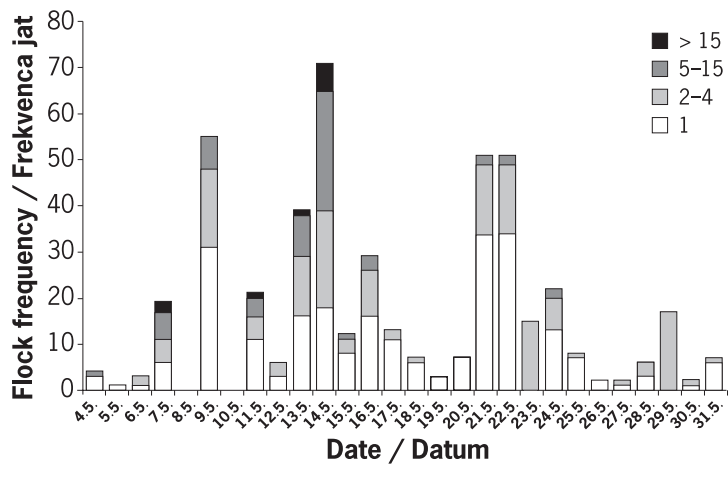

Figure 6: Flock size of migrating raptors (ind.) on Breginjski Stol during the study period given in four size classes

Slika 6: Velikost jat selečih se ujed (os.) na Breginjskem Stolu v raziskovalnem obdobju, podana v štirih velikostnih razredih

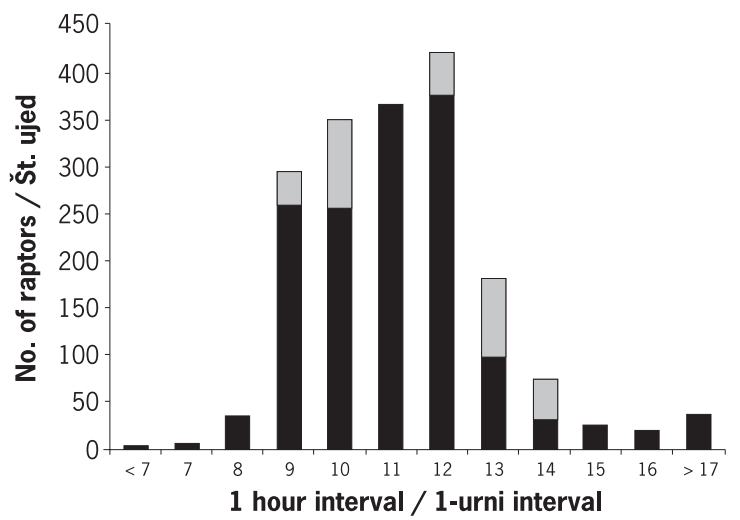

Figure 7: Time distribution of observed migrating raptors on Breginjski Stol in May 2010 during the day, pooled for the entire study period. Black bars represent the actual number of observed individuals, whereas grey bars are the average estimate of missed raptors due to movements of observers between points (see 4.3.).

Slika 8: Časovna razporeditev opazovanih selečih se ujed na Breginjskem Stolu maja 2010 v dnevnem času med celotnim raziskovalnim obdobjem. Crni stolpci ponazarjajo dejansko število opazovanih osebkov, medtem ko so sivi stolpci povprečna ocena zgrešenih ujed zaradi premikov opazovalcev med opazovalnimi točkami (glej 4.3.).

Data on the exact flight route (direction, passing over the summit, above the slope or above the valley) were not gathered and delineated on the maps for all Griffon Vultures, therefore we analysed flight routes for 493 of 575 passes. Similar percentages were seen flying westward above the southern slope (21.8\%), north-westward (19.3\%) and eastward above the ridge (18.2\%). Of other directions, $13.8 \%$ migrated 


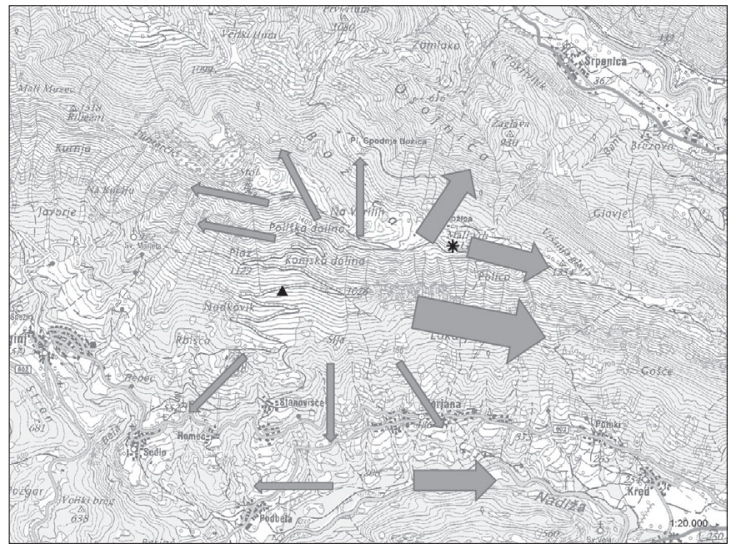

Figure 8: Flight directions of migrating raptors on Breginjski Stol in May 2010 ( $n=1,168$ ind.). The thickness of arrows delineates different percentages of migrating individuals: narrow $0-4 \%$, middle-sized $5-15 \%$ and thick > 60\%. Asterisk - main observation point, triangle - point A.

Slika 8: Smeri letov selečih se ujed na Breginjskem Stolu maja 2010 ( $n=1168$ os.). Debelina puščic ponazarja različne odstotke selečih se osebkov: ozka 0-4\%, srednje debeline $5-15 \%$ in debela $>60 \%$. Zvezdica - glavna opazovalna točka, trikotnik - točka A.

westward above the ridge, $8.9 \%$ eastward above the slope and $6.1 \%$ south-eastward. All other flight directions together amounted to $5.3 \%$ (Figure 5).

\subsubsection{Migratory raptors}

Altogether, 1,510 individuals of migrating raptors were counted, belonging to at least nine species. Among them, Honey Buzzard was the commonest (1,368 ind., $90.6 \%$ of migrating raptors), followed by Marsh Harrier Circus aeruginosus (66 ind., 4.4\%) and Montagu's Harrier C. pygargus (29 ind., 1.9\%). The highest number of migrating raptors (552 ind., of those 537 Honey Buzzards) was observed on 14 May (Table 3).

Most raptors were seen migrating solitarily or in small flocks (2-4 ind.), whereas on five days $(4,7,11$, 13,14 May) over $20 \%$ of all observed flocks were either medium-sized (5-15 ind.) or large (> 15 ind.). It must be stressed, however, that on 4 May only four flocks were observed (one consisted of 13 Honey Buzzards and three of solitary migrating raptors) (Figure 6).

The majority of raptors migrated between 9.00 and 13.00 hrs (Figure 7). Hours before $9.00 \mathrm{hrs}$ and after $17.00 \mathrm{hrs}$ are underrepresented due to limited observation period (normally, observers were present at observation point from 9.00 to $17.00 \mathrm{hrs}$ ). Based on our data for days when monitoring started at least at 8.00 hrs (on 17 days), we conclude that migration in early hours is weak. On those days, $5.7 \%$ of all observed raptors were counted before $9.00 \mathrm{hrs}$. Monitoring after $17.00 \mathrm{~h}$ (at least until $18.00 \mathrm{~h}$ ) was conducted on six days. $8.8 \%$ of all observed migrating raptors on those days were counted after $17.00 \mathrm{hrs}$.

Data on the exact migration route (flight direction, i.e. passing over the summit, above the slope or above the valley) were not gathered and delineated on the maps for all migrating raptors, therefore we analysed migration routes for 1,168 of the 1,510 individuals. The majority of them migrated eastwards $(88.0 \%)$, with $63.8 \%$ passing above the southern slope, $14.6 \%$ above the valley and $6.6 \%$ above the ridge (Figure 8 ). Migration towards north and NE together accounted for $10 \%$ ( $4.4 \%$ and $5.6 \%$, respectively). All other flight directions together amounted to $5 \%$.

\section{Discussion}

\subsection{Residents}

Residents are present in the area throughout the breeding season. They forage and breed there or simply migrate daily over the area while travelling to their foraging sites. Some of them are migratory (e.g. Sparrowhawk, Common Buzzard, Hobby), but their migration period ended before our monitoring started. The only exception to this is Hobby, whose migration lasts until mid-May (Cramp 1980). Nevertheless, we consider it a resident as all individuals were seen in the second half of May.

Griffon Vulture was the most common species among residents, occasionally observed in quite large groups. They migrate daily across Breginjski Stol in search of food. The individuals we observed belong to the reintroduced population from Forgaria nel Friuli, NE Italy (established in 1992) (Minelič \& Genero 2005) and to the breeding population in Kvarner, NW Croatia (F. Genero pers. comm.). The Italian colony is $25-35 \mathrm{~km}$ away from Breginjski Stol. In winter, it consists of approximately 80 Griffon Vultures, while in summer this number increases to 100-130 individuals due to immigrants from Croatia and, to a much lesser extent, from France. There are 20 breeding pairs, which raised at least 11 young in 2010. In 2010, Croatian Vultures arrived in Italy sooner than in previous years, between 15 and 20 May (F. Genero pers. comm.). This coincides perfectly with the increased number of observations at Breginjski Stol from 15 May onwards. The number of Griffon Vulture observations in 2010 is much higher than in previous years (Table 4), which is due to several reasons: (1) higher number of 
Table 4: Overview of raptor monitoring results at Breginjski Stol from 2005-2010

Tabela 4: Pregled rezultatov monitoringa ujed na Breginjskem Stolu v obdobju 2005-2010

\begin{tabular}{|c|c|c|c|c|c|c|c|}
\hline $\begin{array}{l}\text { Year/ } \\
\text { Leto }\end{array}$ & $\begin{array}{l}\text { Observation } \\
\text { period/ } \\
\text { Obdobje } \\
\text { opazovanja }\end{array}$ & $\begin{array}{c}\text { No. of } \\
\text { observation } \\
\text { days/ } \\
\text { Št. } \\
\text { opazovalnih } \\
\text { dni }\end{array}$ & $\begin{array}{l}\text { No. of } \\
\text { raptor } \\
\text { passes/ } \\
\text { Št. preletov } \\
\text { ujed }\end{array}$ & $\begin{array}{c}\text { No. of } \\
\text { passes/ } \\
\text { Št. } \\
\text { preletov } \\
\text { Gyps fulvus }\end{array}$ & $\begin{array}{l}\text { No. of } \\
\text { migrating } \\
\text { raptors/ } \\
\text { Št. selečih se } \\
\text { ujed } \\
\text { (ind. / os.) }\end{array}$ & $\begin{array}{l}\text { Commonest species/ } \\
\text { Najpogostejša vrsta } \\
\text { (No. of ind. / Št. os.) }\end{array}$ & Reference / Vir \\
\hline 2005 & $22.4 .-29.5$ & I6 & 356 & I75 & 320 & Pernis apivorus (303) & Rubinić et al. 2005 \\
\hline 2006 & $29.8 .-29.9$ & 7 & I57 & 52 & 30 & Circus aeruginosus (I4) & Rubinić \& BožIČ 2007 \\
\hline 2009 & І8.8.-3І.8. & I4 & 578 & 340 & I8I & Pernis apivorus (I08) & Rubinić 2009 \\
\hline 2010 & $4.5 .-3 \mathrm{I} .5$. & 28 & 2,385 & 575 & $\mathrm{I}, 5 \mathrm{IO}$ & Pernis apivorus $(\mathrm{I}, 368)$ & this study / ta raziskava \\
\hline
\end{tabular}

observation days, (2) increase of Italian population (F. GENERO pers. comm., http://www.riservacornino.it/ progetto-grifone/, 5 Jul 2010) and (3) the early arrival of Croatian Vultures to the Italian colony (F. GENERo pers. comm.), which coincided with our monitoring period. Otherwise the summer maximum of Vultures on feeding stations in Italy is in the first two decades of June (data for 2009; F. GENERO pers. comm.), which is approximately 2-3 weeks later than in 2010.

We observed Griffon Vultures feeding on Mt Planja (1,663 m a.s.l., $5 \mathrm{~km} \mathrm{~N}$ of Breginjski Stol), most probably on a sheep cadaver (T. Minelič \& T. TRILAR pers. comm.). The same occurred in 2009 (A. FIgELJ pers. comm., Rubinić 2009). Mammal cadavers, fresh or decomposing, are the main food source for this species (CRAMP I980). Occasionally, some vultures spend the night at Breginjski Stol. On 23 Aug 2009, a flock of 21 individuals was observed gathering height just above the summit at $6.00 \mathrm{hrs}$ in the morning. It is highly unlikely that they flew from some other location at such an early hour (RUBINIĆ 2009). It is common for Griffon Vultures to spend the night close to their feeding places (F. GENERO pers. comm.), which might be related to their habit of gorging on carrion to such an extent that they are incapable of taking off (CRAMP I980). Breginjski Stol is therefore not only a fly-over and height-gathering point for Griffon Vultures, but also their regular roosting and feeding place.

In the morning, Griffon Vultures fly from Italy towards Mt Krn (15 km E of Breginjski Stol), whereas in the afternoon they return in the opposite direction (Minelič \& Genero 2005). On both occasions, they fly across Breginjski Stol. This was confirmed by observations in 2010 and by telemetry results of a Croatian vulture equipped with a satellite transmitter and released in the Italian colony (F. GENERO pers. comm.).

In the morning, from approximately 9.30-10.00 hrs onwards, the Griffon Vultures were flying from west to east, soaring above the southern slope or above the ridge of Breginjski Stol. Some of them returned to the west soon after $12.00 \mathrm{hrs}$, while the rest were returning in the afternoon (scattered between 13.00 and $17.00 \mathrm{hrs}$ ). In exceptional cases, Griffon Vultures were flying from the east back to the west in the morning already. Some returned to the west only half an hour after being seen flying to the east (they were recognized by characteristic pattern of missing wing feathers). Breginjski Stol is within their home range, which normally covers areas up to 50-60 km away from their breeding colony (CRAMP 1980). During the monitoring period, Griffon Vultures first appeared on 7 May, which was the first day with no precipitation since the beginning of our monitoring. This might be related to the formation of thermals, which is feasible only in non-rainy weather. Griffon Vultures are excellent soarers that use thermal uplift to gain height and travel (CRAMP I980).

\subsection{Migratory raptors}

Among the observed 1,510 migrating raptors, over $90 \%$ were Honey Buzzards with a peak on 14 May (537 individuals). On this day, thick fog prevailed in the Nadiža valley and on the summit and slopes of Breginjski Stol above 1,100 $\mathrm{m}$ a.s.l.. The only belt of good visibility was from the observation point $A$, between 700 and 1,100 $\mathrm{m}$ a.s.l. (Figure 4).

The most important bottleneck for raptors in the Central Mediterranean, the Strait of Messina (southern Italy), had a peak of migrating raptors on 30 Apr 2010, when 7,026 raptors were counted, the majority of them being Honey Buzzards (RICCIARDI et al. 2010). A considerable proportion of the raptors that cross the Mediterranean at Messina, eventually 
cross the Adriatic Sea at different points along the eastern Italian coast to reach the Balkans (SCHNEIDERJacoby 200i, Gustin \& Sorace 2004, Agostini et al. 2007, Premuda et al. 2008, F. Mezzavilla pers. comm.). The remaining raptors (i.e. those that do not cross the Adriatic Sea) continue their flight towards northern Italy. They fly over the North Adriatic coast and constitute only a minor part of raptors counted near Treviso and the Venice coast (NE Italy) (F. Mezzavilla pers. comm.). Therefore, NE Italy is a juncture of two migration pathways - the one from Gibraltar and the other from Sicily. At Treviso, 769 raptors (mainly Honey Buzzards, Marsh Harriers and Common Buzzards) were counted during 28 Feb-16 May 2006 (35 observation hours), which is a very high number considering the low number of observation hours (Mezzavilla 2006). The majority of raptors observed in northern and NE Italy come from the West (western Italy, Spain and France) and are headed East (F. Mezzavilla pers. comm.). Thus, they are part of the Gibraltar pathway. At the observation points near Lake Garda (northern Italy), several thousand raptors are counted in spring (location Cima Comér on the eastern coast of Lake Garda): Feb-May 2009, 19 observation days, 74 hours of observation, 1,674 raptors (GARGIONI \& ZANARDINI 2009); end of Feb-Mar 2010 several thousand Sparrowhawks and Common Buzzards (Leo 20Io). There is also a strong autumn migration near Lake Garda. In autumn 2009, 1,529 raptors were counted at Prealpi Veronesi (5 km east of Lake Garda); 22,607 raptors at Parco del Mincio (30 km south of Lake Garda); 10,700 raptors at Prealpi Trevigiane (95 km NEE of Lake Garda) and in autumn 2008, 7,886 raptors were counted at Colli Asolani (105 km NEE of Lake Garda) (Sighele et al. 2009, Mezzavilla et al. 2008 \& 2009A, Gargioni et al. 2009). From these observation points northwards and eastwards, the actual migration routes are not clear due to the lower number of observation locations and consequently lack of data (F. Mezzavilla pers. comm.). It is possible that the main migration route splits into several bigger and smaller ones in northern Italy. Raptor migration routes are known to be more dispersed in continental parts of Europe than at sea straits (Zalles \& Bildstein 2000). However, it is now clear from this study that an important percentage of these raptors migrate across Breginjski Stol. Further north there is an observation point at Podklošter / Arnoldstein in the Zilja valley / Gailtal, southern Austria. This valley proved to be the most important raptor migration route in the eastern Alps. At Podklošter, spring migration was monitored in 2008 from February to mid-May (only 20 observation days). 261 raptors were counted, among them mostly Common Buzzards (March) and Honey Buzzards (May) (Рrobst 2009A). In the second half of August, 3,226 raptors were counted in 2007 (of those 3,184 ind. or $98.7 \%$ Honey Buzzards), 3,973 raptors in 2008 (3,769 ind., 94.9\% Honey Buzzards), 4,576 raptors in 2009 (4,427 ind., 96.7\% Honey Buzzards) (Probst 2009A \& 2009B) and from 19 Aug to 1 Sep 2010 4,399 (4,295 ind., 97.6\% Honey Buzzards) (http://www.birdlife.at/kaernten/raptorcamp/2010/ zug/index.html; 2 Sep 2010).

On migration, Honey Buzzards exploit thermals whenever possible to reduce their energy expenditure and the same holds true for Black Kite Milvus migrans (MeYer et al. 2000, HaKe et al. 2003). In the absence of thermal uplift, Honey Buzzards use active flight, which enables them to migrate even in relatively bad weather (BRUDERER et al. 1994). Their exact migration route is determined by the direction of prevailing winds, topography, navigational skills of individual Honey Buzzards (related to age), time of day and season (Leshem \& Yom-Tov 1998, Agostini et al. 2005B). Adult Honey Buzzards on autumn migration mainly fly westwards across France and Spain and cross the Mediterranean at Gibraltar, whereas juveniles cross the Mediterranean at its central part (Sicily, Sardinia, Corsica; HaKe et al. 2003, http://born2bwild.nhmwien.ac.at/BORN_wespenbussard.html\#zug, 6 Dec 2010). They often migrate in flocks, which facilitates the finding of thermals (KerLinger i989, Agostini et al. I994, Agostini et al. 2005A). The largest flock observed on the island of Marettimo (west of Sicily) numbered 147 individuals (Agostini et al. 2005A), on Pantelleria Island (SW of Sicily) 757 individuals and on Panarea Island (north of Sicily) 227 individuals (Agostini et al. 2005B). At Breginjski Stol, the largest flock (observed on 14 May) consisted of 63 individuals. On that day, 45\% of all observed flocks were medium-sized or large.

Migration at our study site normally began between 8.00 and 9.00 hrs. Honey Buzzards were most often first spotted circling and gathering height over the utmost western part of our visual field (western part of Breginjski Stol ridge, summit Muzec and further to the west). Then they flew actively over southern slopes of Breginjski Stol and above the Nadiža valley with infrequent circling and soaring over the slope, which might indicate unfavourable conditions for the development of thermals. This assumption was further supported by their low flight altitude. In sunny weather, altitudes of migrating Honey Buzzards, harriers and kites increase from morning to early afternoon due to the increased thermal convection (Meyer et al. 2000, SPAar et al. 2000, BožIČ 2004, 
R. Probst pers. comm.). Falcons, on the other hand, have a different migration strategy. They do not use thermals very often, but migrate actively, constantly flapping their wings. They can achieve great altitude already in the morning, crossing mountain barriers at different points (MeYer et al. 2000).

\subsection{Bottleneck for migratory raptors}

BirdLife's IBA criterion B1iv defines a bottleneck of European importance as follows: "The site is a "bottleneck site" where 5,000 or more storks (Ciconiidae), or 3,000 or more raptors (Accipitriformes and Falconiformes) or cranes (Gruidae), pass regularly on spring or autumn migration" (HeATH \& Evans 2000). During spring migration in May 2010, we counted almost exactly half $(1,510)$ of the required number of raptors $(3,000)$ at Breginjski Stol.

That the actual number of raptors passing across the area in spring is much higher can be argued by several facts:

\section{(1) Short observation period and limited number of observation hours per day}

We counted raptors only in May, whereas spring migration of some species takes place earlier (Feb-Apr). Based on results of 20 observation days from February to mid-May 2008, R. Probst estimated that as many raptors migrated across Podklošter / Arnoldstein during Feb-Apr as in May alone (R. РRовsт pers. comm.). The majority of Common Buzzards and Sparrowhawks migrate over Carinthia in March (РRовsт 2009A), while at Lake Garda these two species peaked in the second decade of March 2010 (Leo 20Io). Marsh Harriers cross the Mediterranean between 18 Mar and 29 Apr (Strandberg et al. 2008), on the island of Ustica (north of Sicily) they peak in the first decade of April (PANuccio et al. 2004), and the greater part of their migration in Carinthia is observed in April (Probst 2009A). At Medvedce water reservoir (NE Slovenia), Marsh Harriers migrate from the end of March to the end of April (BORdJAn \& Božıč 2009). Migration of all of these species was largely missed in 2010 at Breginjski Stol. Sparrowhawks, similarly to falcons, only rarely use thermals on migration and migrate on a very broad front across mountain chains (BRUDERER et al. 1994). Thus, in case of our study area, they would probably not have contributed many individuals. The situation is reverse with Common Buzzard and harriers, whose migration strategy is similar to that of Honey Buzzard (extensive use of thermals, migration along mountain chains) (BRUDERER et al. 1994). Based on Austrian experiences, we estimate that we missed $50-100 \%$ of migrating raptors (calculated from the number of observed individuals in May) due to limited observation period. This amounts to approximately 760 to 1,510 individuals that passed through the area in early spring (Feb-Apr).

Some of the raptors was missed due to the limited number of observation hours per day. Normally, our monitoring started at 9.00 and ended at 17.00 hrs. Based on test observations in late afternoon and evening hours, Petutschnig \& Probst (20Io) estimated that due to the limited number of observation hours per day they missed 5-15\% raptors at Podklošter / Arnoldstein (those were raptors migrating after the official end of monitoring at $17.00 \mathrm{hrs})$. At Breginjski Stol, $5.7 \%$ of all observed migrating raptors were counted before $9.00 \mathrm{hrs}$ and $8.8 \%$ after $17.00 \mathrm{hrs}$ (this calculation is based on days when monitoring started at least at $8.00 \mathrm{hrs}$ and lasted at least until 18.00 hrs, respectively). Therefore, we estimate that by limiting observation hours from $9.00-17.00 \mathrm{hrs}$, we missed $10-15 \%$ of migrating raptors (approximately 150-230 ind.) which coincides very well with data from Austria (Petutschnig \& Probst 20io).

(2) Overlooked raptors due to human- and topography-related reasons

A proportion of the migrating raptors was surely overlooked, despite the fact that in most cases two observers monitored the sky simultaneously. In Canada, observers saw only $41-78 \%$ of migrating raptors with the percentage of overlooked raptors being smaller for soaring than for active-flying raptors. Efficiency of observers was increased when the density of migrating raptors was high (SATTLER $\&$ BART 1984). In Carinthia, the percentage of overlooked raptors due to human factor was $10-20 \%$ and due to high flight altitudes $10-35 \%$ (when the temperature exceeded $25^{\circ} \mathrm{C}$ ). Smaller, faster, solitary birds and smaller flocks were more often overlooked than larger flocks and large birds (Petutschnig \& Probst 20io, R. Probst pers. comm.). At Breginjski Stol, we only had five days with more than $20 \%$ of all observed flocks being medium-sized or large, whereas on other occasions raptors migrated solitarily or in small flocks. Thus, the probability of overlooking them was higher. We estimate that $10-20 \%$ of raptors were missed due to human factor (approximately 150-300 ind.).

A proportion of the raptors was overlooked due 
to topography reasons. The ridge of Breginjski Stol is $11 \mathrm{~km}$ long and undulating. Based on our experience and local topography, an observer using a spotting scope can cover distances of ca. $4 \mathrm{~km}$ from the main observation point Mali vrh, although for accurate determination most bird species have to be closer (MAdDers \& Whitfield 2006). All raptors that crossed Breginjski Stol perpendicular to the ridge on locations farther from the observation point than $4 \mathrm{~km}$ were overlooked. These probably included falcons (e.g. Red-footed Falcon Falco vespertinus) that can migrate at $90^{\circ}$ to mountain chains (Meyer et al. 2000, Рrobst 2009A), but also some Honey Buzzards and Marsh Harriers (based on own and observations of other observers). 3.4\% of all observed migrating raptors crossed Breginjski Stol perpendicular to the ridge. The problem of topography could be alleviated through an additional observation point west of Mali vrh. In Carinthia, 5-20\% of raptors at main observation point are overlooked because they exit the Zilja valley already at Korensko sedlo / Wurzenpass on the border between Austria and Slovenia, ca. $6 \mathrm{~km}$ east of the main observation point (Petutschnig \& Probst 20io). Due to frequent bad weather, most monitoring was done from point $A$ on the southern slope. This means that we were unable to cover the northern slope and the Učja valley, where at least some migration also took place (e.g. 15 Honey Buzzards on 4 May that entered the Soča valley from the Učja valley). Additionally, the visibility at this point is somewhat poorer that at Mali vrh due to terrain configuration. Taking into consideration all the above mentioned topography reasons, we estimate that we missed $5-15 \%$ of raptors (approximately 80 to $230 \mathrm{ind}$.).

\section{(3) Movements of observers between observation points}

Due to difficult weather conditions, especially fog, observers had to move between observation points. While travelling from one point to the other they missed a certain number of raptors. At least three groups of observers came across strong Honey Buzzard migration when they arrived at point $\mathrm{A}$, because of fog, at Mali vrh. One observer group needed $2 \mathrm{~h}$ to move between the points (from 9.00-11.00 hrs), the second one 1.5 $\mathrm{h}$ (from 9.00-10.30 h) and the third one $2.5 \mathrm{~h}$ (from 12.30-15.00 h). Judging from the intensity of migration, the duration of the observers' movements and the usual time of beginning of migration we estimate that we missed 260-350 raptors (50-90 ind. on 7 May, 50-70 ind. on 9 May and 160-190 ind. on 13 May).

\section{(4) Weather}

May 2010 was extremely rainy and foggy $(396 \mathrm{~mm}$ of precipitation compared to long term average of ca. $250 \mathrm{~mm}$; Cegnar \& Gorup 20io), which occasionally completely prevented observation. On 15 out of 28 days there was at least occasional rain, whereas fog was even more frequent. Some of our own but also foreign data show that Honey Buzzard migration can proceed even in such conditions (R. Probst pers. comm.; observations at Breginjski Stol on 11 and 13 May 2010). In Canada, only $20 \%$ of migrating raptors were seen when visibility was low due to bad weather (SATTLER \& BART 1984). Some rainless days in our study area were apparently appropriate for raptor migration, but the day totals were very low (e.g. 19 and 20 May - on these two days only nine Honey Buzzards were counted). Strong northern wind was blowing on these two days, opposite of the migrating raptor direction. There is some evidence that raptors do not fly in strong opposing winds, but prefer flying in tailwinds (MEYer et al. 2000). Similar changing winds, frequent fog and low clouds were experienced in 2010 at Messina, which resulted in much dispersed raptor migration flow (Ricciardi et al. 20IO). We estimate that 10-30\% of raptors were missed due to frequent bad weather (especially fog) and consequently poor visibility (approximately 150 to $450 \mathrm{ind}$.).

\section{(5) Night migration}

Most raptors migrate during the day (ZALles \& BildsteIN 2000), but some also during the night. As much as $33-34 \%$ of falcons and $15-20 \%$ of harriers cross the Mediterranean at night (MEYer et al. 2003). Honey Buzzard predominantly migrates during the day (in autumn almost exclusively from 8.00 to 16.00 hrs; HaKe et al. 2003), but there is also information on its night migration (AgostinI et al. 2005C). For night observations, radars are used. They enable individual birds to be tracked up to 8 $\mathrm{km}$. Based on flight pattern, identification to the species level is possible (Bruderer et al. 1994, MEYER et al. 2000 \& 2003). As data on night migration of raptors over the continental parts of Europe is very scarce (Gatter 1984, R. Probst pers. comm.) and night migration is uncommon in Honey Buzzard, we estimate that $0-5 \%$ of raptors were missed due to this phenomenon (approximately $0-80$ ind.). 
Table 5: Estimate of the number of overlooked raptors at Breginjski Stol in May 2010 due to different reasons

Tabela 5: Ocenjeno število prezrtih ujed na Breginjskem Stolu maja 2010 zaradi različnih vzrokov

\begin{tabular}{|c|c|c|}
\hline Reason / Razlog & $\begin{array}{l}\text { Overlooked raptors/ } \\
\text { Prezrte ujede }(\%)^{*}\end{array}$ & $\begin{array}{l}\text { No. of overlooked raptors/ } \\
\text { Št. prezrtih ujed }{ }^{* *}\end{array}$ \\
\hline $\begin{array}{l}\text { Short observation period/ } \\
\text { Kratko obdobje opazovanja }\end{array}$ & $50-100$ & $760-1,510$ \\
\hline $\begin{array}{l}\text { Limited no. of observation hours per day/ } \\
\text { Omejeno št. opazovalnih ur na dan }\end{array}$ & IO-IS & $150-230$ \\
\hline Human factor / Človeški dejavnik & $10-20$ & $150-300$ \\
\hline Topography / Topografija & $5-15$ & $80-230$ \\
\hline $\begin{array}{l}\text { Movements of observers between observation points/ } \\
\text { Premiki opazovalcev med opazovalnimi točkami }\end{array}$ & $17-23$ & $260-350$ \\
\hline Weather / Vreme & $10-30$ & $150-450$ \\
\hline Night migration / Nočna selitev & $0-5$ & $0-80$ \\
\hline Total / Skupaj & - & $1,550-3,150$ \\
\hline
\end{tabular}

* Calculated from the total no. of migrating raptors counted (1,510 ind.) / Izračunano iz skupnega št. preštetih selečih se ujed (1510 os.)

** Numbers are rounded to the nearest 10 / Števila so zaokrožena na desetice

Due to different reasons, especially short observation period, we therefore overlooked or missed 1,550-3,150 raptors (Table 5).

Taking into consideration these numbers, we estimate that 3,060-4,660 raptors flew across Breginjski Stol during spring migration 2010, which confirms the site as a bottleneck for migrating raptors. Earlier observations and randomly gathered data (117 migrating raptors, mostly Honey Buzzards on four days between 25 Apr and 16 May 2003; Božič 2004), indicated high raptor concentrations during migration, but numbers were always lower than 600 individuals. It is possible that Breginjski Stol is a bottleneck only in spring. Autumn numbers are much lower, which might reflect a more dispersed autumn migration (Agostini \& PAnUCcio 2005), but also different migration routes in autumn as known for Honey Buzzard in Israel (Bruderer et al. 1994).

Based on data from Italy and Austria, there might be another important area for migrating raptors in western Slovenia, probably between Nova Gorica and Tolmin (R. Probst \& F. Mezzavilla pers. comm.). In autumn 2009, 4,427 Honey Buzzards were counted at Podklošter / Arnoldstein (Рrobst 2009B), whereas at Colli Asolani (105 km NEE of Lake Garda) 11,000 Honey Buzzards were observed (F. Mezzavilla pers. comm.). All the "missing" Honey Buzzards approximately 6,500 individuals - must have arrived at Colli Asolani from Slovenia (F. Mezzavilla pers. comm.). The potential bottleneck at Nova Gorica is further supported by an autumn observation of 333 Honey Buzzards in one day over the city of Krmin /
Cormons near the Italian part of Gorica / Gorizia (Mezzavilla et al. 2009B; F. Mezzavilla pers. comm.).

Acknowledgments: My deepest thanks go to dedicated observers, who were not scared to face the rough conditions at Breginjski Stol (in alphabetical order): Tilen Basle, Nataša Bavec, Dejan Bordjan, Luka Božič, Igor Brajnik, Damijan Denac, Boris Dolenc, Andrej Figelj, Jernej Figelj, Matteo Giraldi (IT), Jurij Hanžel, Aleš Jagodnik, Ana Jančar, Tomaž Jančar, Matjaž Kerček, Primož Kmecl, Franca Legnani (IT), Tomaž Mihelič, Alen Ploj, Matjaž Premzl, Borut Rubinić, Sanja Rubinić, Matteo Skodler (IT), Andreja Slameršek, Željko Šalamun, Anže Škoberne, Aleš Tomažič, Paul Tout (IT), Cristian Trani (IT), Tomi Trilar and Barbara Vidmar. This article was enriched through valuable comments of Remo Probst (BirdLife Austria), Fulvio Genero (Riserva naturale regionale Lago di Cornino, Italy), Francesco Mezzavilla (Faunisti Veneti, Italy) and an anonymous reviewer. The study was partly financially supported by the Ministry of the Environment. 


\section{Povzetek}

Med 4. in 31.5.2010 smo na Breginjskem Stolu (SZ Slovenija) vsak dan med 9. in 17. uro spremljali selitev ujed. Zabeležili smo 2385 preletov ujed, ki so pripadale vsaj 17 vrstam. Stalnice ( $\mathrm{n}=875$ preletov) so se na območju prehranjevale, gnezdile ali se čezenj dnevno selile med iskanjem hrane drugod. Med njimi je bil najpogostejši beloglavi jastreb Gyps fulvus $(\mathrm{n}=$ 575 preletov), katerega največja jata (35 os.) je bila zabeležena 26.5. V dopoldanskem času so beloglavi jastrebi leteli z zahoda proti vzhodu in iskali hrano, $\mathrm{v}$ popoldanskem času pa so se vračali v nasprotni smeri v svojo kolonijo v Furlaniji. Njihovo število se je povečalo po 15.5., ko so se italijanskim jastrebom pridružili še hrvaški. Med selečimi se ujedami smo zabeležili 1510 osebkov, ki so pripadali vsaj devetim vrstam. Med njimi je bil najpogostejši sršenar Pernis apivorus (1368 os., 90,6 \% selečih se ujed). Višek selitve je bil dosežen 14.5. s 552 osebki. Večina ujed se je selila posamič ali v majhnih jatah (2-4 os.), v petih dneh (4., 7., 11., 13. in 14.5.) pa je bilo nad $20 \%$ vseh jat srednje velikih $(5-15$ os.) ali velikih (>15 os.). Glavnina selitve je potekala med 9. in 13. uro. Upoštevajoč nekaj dejavnikov - kratko opazovalno obdobje, omejeno število opazovalnih ur na dan, spregledane ujede zaradi človeškega faktorja in topografije, premike opazovalcev med točkami, izredno slabo vreme in nočno selitev ujed - ocenjujemo, da je Breginjski Stol na spomladanski selitvi leta 2010 preletelo 3060-4660 ujed. S tem Breginjski Stol kot prvo tovrstno območje v Sloveniji izpolnjuje IBA kriterij B1iv za ozko grlo za seleče se ujede in pomeni nadaljevanje selitvenih poti ujed iz severne Italije.

\section{References}

Agostini, N., Logozzo, D. \& Melotto, S. (i994): The flocking behaviour of migrating Honey Buzzards. Bollettino di Zoologia 61 (1): 63.

Agostini, N. \& Panuccio, M. (2005): Analysis of the spatial migration patterns of adult Honey Buzzards (Pernis apivorus) during spring and autumn in the Central Mediterranean. - The Ring 27 (2): 215-220.

Agostini, N., Premuda, G., Mellone, U., Panuccio, M., Logozzo, D., Bassi, E. \& Cocchi, L. (2005A): Influence of wind and geography on orientation behaviour of adult Honey Buzzards Pernis apivorus during migration over water. - Acta ornithologica 40 (1): 71-74.

Agostini, N., Cardelli, C. \& Gustin, M. (2005B): Factors shaping pathways of European Honey Buzzards (Pernis apivorus) during spring migration in the Central Mediterranean basin. - Journal of Raptor Research 41 (1): 57-61.
Agostini, N., Panuccio, M. \& Massa, B. (2005c): Flight behaviour of Honey Buzzards (Pernis apivorus) during spring migration over the sea. - Buteo 14: 3-9.

Agostini, N., Panuccio, M., Melone, U., Lucia, G., Wilson, S. \& Ashton-Booth, J. (2007): Do migration counts reflect population trends? A case study of the Honey Buzzard Pernis apivorus. - Ardeola 54 (2): 339-344.

Bordjan, D. \& BožIČ, L. (2009): Pojavljanje vodnih ptic in ujed na območju vodnega zadrževalnika Medvedce (Dravsko polje, SV Slovenija) v obdobju 2002-2008. Acrocephalus 30 (141/142/143): 55-163.

Božıč, L. (2004): Rjavi škarnik Milvusmilvus. - Acrocephalus 25 (123): 222-225.

Bruderer, B., Blitzblau, S. \& Peter, D. (I994): Migration and flight behaviour of Honey Buzzards Pernis apivorus in southern Israel observed by radar. - Ardea 82: 111-122.

Busse, P., Fornasari, L. \& Yosef, R. (2002): South of the sea: long term results of migrating raptors spring counts along the Polish Baltic coast. pp. 97-101 In: Yosef, R., Miller, M.R. \& Pepler, D. (eds.): Raptors in the new millennium. - International Birds \& Research Center in Eilat, Eilat.

Cegnar, T. \& Gorup, T. (20Io): Podnebne razmere v maju 2010. - Naše okolje. Bilten Agencije RS za okolje 17 (5): $3-22$.

Cramp, S. (ed.) (1980): Handbook of the Birds of Europe, the Middle East and North Africa. The Birds of the Western Palearctic. Vol. II. Hawks to Bustards. - Oxford University Press, Oxford.

Fridl, J., Kladnik, D., Orožen Adamič, M. \& Perko, D. (eds.) (I998): Geografski atlas Slovenije. Država v prostoru in času. - DZS, Ljubljana.

GARgIONI, A. \& ZanARDInI, F. (2009): [The spring migration of raptors at Cima Comér (BS).] - Infomigrans 23: 9. (in Italian)

Gargioni, A., Bellintani, S., Pasqua, A. \& Rigon, R. (2009): [The post-reproductive migration of raptors in the Parco del Mincio (hills of Lake Garda, MN, BS, VR).] - Infomigrans 24: 10. (in Italian)

Gatter, W. (I984): Nachtzug der Rohrweihe (Circus aeruginosus). - Vogelwarte 32: 309-311.

Gustin M. \& Sorace, A. (2004): Is the Conero promontory, central Italy, an important bridge for migrant raptors entering eastern Europe in spring? - British Birds 97 (8): 403-406.

Hake, M., Kjellén, N. \& Alerstam, T. (2003): Agedependent migration strategy in honey buzzards Pernis apivorus tracked by satellite. - Oikos 103: 385-396.

Heath, M.F. \& Evans, M.I. (eds.) (2000): Important Bird Areas in Europe: priority sites for conservation. BirdLife Conservation Series No. 8. Vol. 1 \& 2. - BirdLife International, Cambridge.

Leo, R. (20IO): [The spring migration of raptors at Cima Comér (BS).] - Infomigrans 25: 9. (in Italian)

Leshem, Y. \& Yom-Tov, Y. (I998): Routes of migrating soaring birds. - Ibis 140: 41-52.

Madders, M. \& Whitfield, D.P. (2006): Upland raptors and the assessment of wind farm impacts. - Ibis 148: 43-56. 
Meyer, S.K., SpaAr, R. \& Bruderer, B. (2000): To cross the sea or to follow the coast? Flight directions and behaviour of migrating raptors approaching the Mediterranean coast. - Behaviour 137: 379-399.

Meyer, S., Spaar, R. \& Bruderer, B. (2003): Sea crossing behaviour of falcons and harriers at the southern Mediterranean coast of Spain. - Avian Science 3 (2/3): 153-162.

Mezzavilla, F. (2006): [First data on spring migration of raptors on the plains of Treviso (TV).] - Infomigrans 17: 10. (in Italian)

Mezzavilla, F., Martignago, G., Silveri, G. \& Piccolo, F. (2008): [The post-reproductive migration of raptors over the Asolo, Maser TV - the year 2008.] - Infomigrans 22: 7. (in Italian)

Mezzavilla, F., Martignago, G., Silveri, G. \& Piccolo, F. (2009A): [The post-reproductive migration of raptors at Prealpi Trevigiane. The year 2009.] - Infomigrans 24: 9. (in Italian)

Mezzavilla, F., Gargioni, A., Girardello, M., Bellintani, S., Martignago, G., Pasqua, A., Silveri, G. \& Piccolo, F. (2009B): An important flyway for raptors in Europe: 13 years of monitoring in the North East of Italy. - Avocetta 33: 1-6.

Minelič, T. \& Genero, F. (2005): Occurence of Griffon Vulture Gyps fulvus in Slovenia in the period from 1980 to 2005. - Acrocephalus 26 (125): 73-79.

Panuccio, M., Agostini, N. \& Massa, B. (2004): Spring raptor migration at Ustica, southern Italy. - British Birds 97: 400-414.

Peršolja, T. (2006): Geografija Breginjskega kota. Diplomsko delo. Univerza v Ljubljani, Filozofska fakulteta, Oddelek za geografijo.

Petutschnig, D. \& Probst, R. (2010): Wieviele Greifvögel ziehen tatsächlich durch das Untere Gailtal? - Carinthia II 120 (200): 133-142.

Premuda, G., Gustin, M., Pandolfi, M., Sonet, L. \& Cento, M. (2008): Spring raptor migration along the Adriatic coast (Italy): a comparative study over three sites. - Avocetta 32: 13-20.

Probst, R. (2009A): Der Greifvogelzug 2007 und 2008 über dem Unteren Gailtal, Kärnten. - Carinthia II 119 (199): 393-412.

Probst, R. (2009B): Der Greifvogelzug im Unteren Gailtal im Herbst 2009. Bericht von BirdLife Österreich, Landesgruppe Kärnten, an das Amt der Kärntner Landesregierung, Abteilung 20. - Landesplanung, UAbt. Naturschutz. Feldkirchen.

Ricciardi, D., Garavaglia, R., Ardizzone, D., Chiofalo, G., Fiott, J.P., Vella, R., Adami, I., Cutini, S., Giordano, A. \& Adragna, F. (20IO): [Strait of Messina (the Sicilian side): 27 years of activity, 1 April-23 May 2010.] - Infomigrans 25: 2-3. (in Italian)

Rubinić, B., Mihelič, T. \& BožIČ, L. (2005): Monitoring populacij izbranih vrst ptic. Vmesno poročilo. Rezultati popisov v sezoni 2005. Naročnik: Ministrstvo za okolje in prostor. - DOPPS, Ljubljana.
Rubinić, B. \& Božıč, L. (2007): Monitoring populacij izbranih vrst ptic 2006/07. Končno poročilo. Rezultati popisa beloglavega jastreba jeseni 2006 in Januarskega štetja vodnih ptic (IWC) 2007. Naročnik: Ministrstvo za okolje in prostor. - DOPPS, Ljubljana.

Rubinić, B. (2009): Monitoring populacij izbranih vrst ptic. Končno poročilo (november 2009). Naročnik: Ministrstvo za okolje in prostor. - DOPPS, Ljubljana.

SAtTler, G. \& BART, J. (1984): Reliability of counts of migrating raptors: an experimental analysis. - Journal of Field Ornithology 55 (4): 415-537.

Schneider-Jacoby, M. (200I): Lastovo - a new bottleneck site for the migratory Honey Buzzards Pernis apivorus? Acrocephalus 22 (108): 163-165.

Sighele, M., Lerco, R. \& Izzo, C. (2009): [The postreproductive migration of raptors at Prealpi Veronesi (VR).] - Infomigrans 24: 7. (in Italian)

SPAAR, R. (I999): Flight behaviour of migrating raptors under varying environmental conditions. pp. 1844-1862 In: Adams, N.J. \& Slotow, R.H. (eds.): Proceedings of the $22^{\text {nd }}$ International Ornithological Congress, 16-22 August 1998, Durban. - BirdLife South Africa.

SpAAR, R. \& BrUderer, B. (I997): Migration by flapping or soaring: flight strategies of Marsh, Montagu's and Pallid Harriers in Southern Israel. - Condor 99: 458-469.

SpaAr, R., Liechti, O. \& Bruderer, B. (2000): Forecasting flight altitudes and soaring performance of migrating raptors by the altitudinal profile of atmospheric conditions. - Technical soaring 24 (2): 49-55.

Strandberg, R., KlaAssen, R.H.G., Hake, M., Olofsson, P., Thorup, K. \& Alerstam, T. (2008): Complex timing of Marsh Harrier Circus aeruginosus migration due to pre- and post-migratory movements. - Ardea 96 (2): 159-171.

Zalles, J.I. \& Bildstein, K.L. (eds.) (2000): Raptor watch. A global directory of raptor migration sites. BirdLife Conservation Series No. 9. - BirdLife International \& Hawk Mountain Sanctuary.

Arrived / Prispelo: 14.9.2010

Accepted / Sprejeto: 22.6.2011 